\title{
Pengembangan Media Sepeda (Sistem Peredaran Darah) dalam Pembelajaran IPA di Sekolah Dasar
}

\section{Prastyaning Hidayah $^{1 *}$, Mei Fita Asri Untari ${ }^{2}$, M. Yusuf Setya Wardana ${ }^{3}$}

1,2,3 Jurusan PGSD, FIP Universitas PGRI Semarang

\section{ARTICLEIN \\ $\mathrm{FO}$ \\ Article history: \\ Received 12 August \\ 2018 \\ Received in revised form \\ 17 September 2018 Accepted 18 October Available online 27 November 2018 \\ Kata Kunci: \\ Media SEPEDA, \\ Keefektifan media, \\ Kevalidan media \\ Keywords: \\ SEPEDA media, \\ media effectiveness, media validity}

\begin{abstract}
A B STRAK
Penelitian ini dilatar belakangi karena rendahnya nilai siswa khususnya pada mata materi sistem peredaran darah yang diakibatkan oleh proses pembelajaran yang kurang aktif, kreatif, dan inovatif. Penelitian ini bertujuan untuk mengetahui keefektifan dan kevalidan media SEPEDA pada siswa kelas $\mathrm{V}$ di tiga sekolah yaitu SDN Blimbing 1, SDN Kedungmundu, dan SDN sendangmulyo 01. Penelitian ini adalah penelitian Research and Development. Perolehan hasil nilai validasi ahli media sebanyak $96 \%$ dengan kriteria "sangat baik" dan nilai validasi materi sebanyak $63 \%$ dengan kriteria "baik". Populasi dalam penelitian ini adalah siswa kelas V di SDN Blimbing 1 tahun ajaran 2017/2018. Hasil dari perolehan nilai rata-rata preetest 10,3 dengan kriteria "sangat kurang" dimana nilai tertinggi 30 dan nilai terendah 0 . Sedangkan perolehan nilai rata-rata Posttest siswa sebanyak 67,4 dengan kriteria "baik" dimana nilai tertinggi sebanyak 100 dan nilai terendah 20 .
\end{abstract}

\section{A B S T R A C T}

This research is motivated by the low value of student, especially in the circulatory system material caused by the lerning process that is active, creative, and innovative. This study aims to determine the effectiveness and validity of SEPEDA media in fifth grade students in three schools, SDN Blimbing 1, SDN Kedungmundu, SDN Sendangmulyo 01. This research is "research and development". The result of media validation value were $96 \%$ with criteria of "good". The population in the study was grade V students at SDN Blimbing 1 academic year 2017/2018. The result of the acquisition of the preetest average score of 10,3 with the criteria of "very less" where the highest score in 30 and the lowest value is 0 . While the acquisition of the average posttest score of student is 67,4 with the criteria of "good" where the highest score is 100 and values lowest 20 .

\footnotetext{
* Corresponding author.

E-mail addresses: prastyaningh@gmail.com (Prastyaning Hidayah)
} 


\section{Pendahuluan}

Pembelajaran berorientasi pada aktivitas siswa yang dapat dipandang sebagai suatu pendekatan dalam pembelajaran yang menekankan pada aktivitas siswa secara optimal untuk memperoleh hasil belajar yang berupa perpaduan antara aspek kognitif, afektif, dan psikomotor secara seimbang (Walid 2017: 4). Menurut bab IV pasal 19 peraturan pemerintah No. 19 tahun 2005 bahwa proses pembelajaran pada satuan pendidikan diselenggarakan secara interaktif, inspiratif, menyenangkan, menantang, memotivasi peserta didik untuk berpartisipasi aktif, serta memberikan ruang yang cukup bagi prakarsa, kreativitas, dan kemandirian sesuai dengan bakat, minat, dan perkembangan fisik serta psikologis peserta didik.Dan berdasarkan UURI No. 20 tahun 2003 tentang Sistem Pendidikan Nasional bab I pasal 1 menyatakan, bahwa pendidikan adalah usaha sadar dan terencana untuk mewujudkan suasana belajar dan proses pembelajaran agar peserta didik secara aktif mengembangkan potensi dirinya menjadi menusia berkualitas sesuai dengan tujuan pendidikan. Untuk menerapkan apa yang tertulis didalam peraturan pemerintah dan UU Sistem Pendidikan,maka dalam pembelajaran guru tidak bisa mengajar hanya dengan menggunakan metode ceramah, karena dapat membuat siswa merasa bosan akibatnya siswa tidak dapat memahami apa yang disampaikan oleh guru tersebut. Maka untuk mengatasi hal tersebut penggunaan media sebagai alat bantu sangatlah diperlukan sebagai alat bantu dalam pembelajaran.

Pembelajaran IPA di Sekolah Dasar merupakan pondasi awal dalam menciptakan siswa-siswa yang memiliki pengetahuan, keterampilan dan sikap ilmiah. Pembelajaran IPA diarahkan dengan cara mencari tahu tentang alam secara sistematis, sehingga IPA bukan hanya merupakan penguasaan kumpulan pengetahuan yang berupa fakta-fakta, konsep-konsep, atau prinsip-prinsip saja, tetapi juga merupakan suatu proses penemuan dan pembentukan sikap ilmiah. Hakikat sains adalah landasan untuk berpijak dalam mempelajari IPA. Menurut Mariana dan Praginda (2009) hakikat Ilmu Pengetahuan Alam (IPA) merupakan makna alam dan berbagai fenomena/perilaku/karakteristik yang dikemas menjadi sekumpulan teori dan konsep melalui serangkaian proses ilmiahyang dilakukan manusia.Banyak cara yang telah dilakukan untuk mencapai aspek yang terkandung di dalam hakikat sains, namun belum juga menunjukkan hasil yang memuaskan. Disamping itu juga guru belum memahami konsep hakikat sains.

Tursinawati (2010) menjabarkan bahwa hakikat IPA meliputi empat unsur, yaitu: (1) sikap: rasa ingin tahu tentang benda, fenomena alam, makhluk hidup, serta hubungan sebab akibat yang menimbulkan masalah baru yang dapat dipecahkan melalui prosedur yang benar; sains bersifat open ended; (2) proses: prosedur pemecahan masalah melalui metode ilmiah; metode ilmiah meliputipenyusunan hipotesis, perancangan eksperimen atau percobaan, evaluasi, pengukuran, dan penarikan kesimpulan; (3) produk: berupa fakta, prinsip, teori, dan hukum; (4) aplikasi: penerapan metode ilmiah dan konsep IPA dalam kehidupan sehari-hari. Dari hasil penelitian menggambarkan pentingnya aspek hakikat sains dalam proses pembelajaran IPA. Tursinawati (2010) menjelaskan tentang peningkatan pemahaman siswa pada aspek sains sebagai sikap berada pada kategori yang paling rendah dibandingkan dari aspek lain pada hakikat sains.

Untuk mencapai hakikat sains secara utuh membutuhkan upaya dan kompetensi guru untuk memuat aspek hakikat sains dalam proses pembelajaran IPA. Percobaan pada pembelajaran IPA merupakan bentuk sederhana dari aspek sains sebagai proses yaitu melakukan kegiatan ilmiah sehingga membangkitkan motivasi siswa menjadi seorang ilmuan di masa akan datang. Walaupun demikian sikap ilmiah menjadi aspek yang sangat penting dalam melaksanakan percobaan-percobaan (kegiatan ilmiah sederhana). Sikap ilmiah siswa menjadi tolak ukur ketika penelitian para ilmuan dalam menjalani kegiatan ilmiah. Apabila sikap ilmiah siswa dalam melaksanakan percobaan tidak dimilikinya, maka akan berdampak negatif kepada produk sains atau teknologi yang mereka hasilkan. Oleh sebab itu sikap ilmiah dalam melaksanakan percobaan pada proses pembelajaran menjadi syarat mutlak yang harus diketahui dan dimiliki oleh peserta didik.

Media merupakan kata yang berasal dari bahasa latin "medius", yang secara harfiah berarti perantara atau pengantar (Wiarto 2016: 2). Media merupakan sarana pembelajaran yang digunakan untuk menyampaikan informasi kepada siswa yang bertujuan untuk membuat tahu siswa. Media adalah pembawa pesan yang berasal dari suatu sumber pesan (dapat berupa orang atau benda) kepada penerima pesan. Media dapat digunakan dalam proses belajar mengajar dengan dua arah yaitu sebagai alat bantu mengajar dan sebagai media belajar yang dapat digunakan sendiri oleh siswa. Media yang dipakai sebagai alat bantu mengajar disebut dependent media. Kajian psikologis menyatakan bahwa anak akan lebih mudah mempelajari hal yang konkrit ketimbang yang abstrak. Berkaitan dengan hubungan konkritabstrak dan kaitannya dengan penggunaan media pembelajaran. Sebagai alat bantu efektifitas media sangatlah tergantung pada cara dan kemampuan guru dalam menggunakan alat tersebut, jadi guru harus dituntut lebih pandai dan kreatif dalam menggunakan media pembelajaran. 
Menurut Wiarto (2016: 3) media merupakan sarana pembelajaran yang digunakan untuk menyampaikan informasi kepada siswa yang bertujuan untuk memberi tahu siswa. Atau bisa diartikan bahwa media adalah pembawa pesan yang berasal dari suatu sumber pesan kepada penerima pesan. Dalam suatu proses belajar mengajar, pesan yang disalurkan oleh media dari sumber pesan ke penerima pesan itu ialah materi pelajaran. Dengan kata lain pesan itu adalah isi pelajaran yang berasal dari kurikulum yang disampaikan guru kepada siswa.

Berdasarkan observasi dan wawancara SD N Kedungmundu Semarang dengan jumlah siswa kelas V sebanyak 38 siswa, SD N Sendangmulyo 01 dengan jumlah siswa kelas V sebanyak 44 siswa, dan SD N Blimbing 1 dengan jumlah sebanyak 27 siswa. Berdasarkan hal tersebut terdapat beberapa siswa yang belum tuntas KKM khususnya materi sistem peredaran darah mata pelajaran IPA. Hal ini dapat disebabkan karena siswa kurang berkonsentrasi dalam pembelajaran yang menyebabkan rendahnya minat dan motivasi belajar siswa karena dimungkinkan karena terbatasnya sumber belajar. Pembelajaran kurang menarik dan cenderung membosankan hal ini dapat dikarenakan guru tidak menggunakan bantuan media sama sekali dalam menyampaikan materi sehingga siswa merasa pembelajaran tentang sistem peredaran darah yang berhubungan langsung dengan mereka terasa abstrak karena setiap pembelajaran siswa harus mengkhayal membayangkan apa yang dijelaskan. Selain itu siswa juga kurang bersungguh-sungguh dalam mengerjakan tugas dari guru, bahkan siswa juga tidak berani menanyakan materi yang belum dipahaminya sehingga siswa kurang aktif dalam proses pembelajaran yang menyebabkan nilai yang diperoleh siswa dibawah KKM.

Berdasarkan penelitian yang dilakukan Mochamad Kamil Budiarto (2017) dengan judul "Pengembangan Multimedia Pembelajaran Materi Sistem Peredaran Darah Pada Manusia Mata Pelajaran IPA Kelas V SD Negeri Karangmloko 2". Pengembangan multimedia merupakan media pembelajaran untuk pokok materi sistem peredaran darah mata pelajaran IPA kelas $\mathrm{V}$ tidak hanya mengemas materi kedalam suatu multimedia saja, melainkan proses pengembangannya disesuaikan dengan prinsip-prinsip multimedia, karakteristik peserta didik dengan harapan siswa akan tertarik dengan multimedia pembelajaran yang berisi materi mengenai sistem peredaran darah.

Melihat pembahasan diatas, maka peneliti memiliki solusi untuk membuat suatu hal yang menarik untuk siswa. Pengajaran akan lebih menarik perhatian dan dapat menumbuhkan motivasi belajar siswa jika media yang digunakan adalah media yang menarik dan menyenangkan. Tidak semata-mata hanya menggunakan komunikasii verba melalui penuturan kata-kata oleh guru, sehingga siswa tidak menjadi bosan dan guru juga tidak kehabisan tenaga jika guru mengajar untuk setiap jam pelajaran.

Penelitian ini peneliti menggunakan Media SEPEDA merupakan media yang dapat dijadikan solusi dalam menyampaikan materi sistem peredaran darah pada manusia, yang berbentuk seperti replika alat peredaran darah pada manusia yang apabila salah satu ujung selangnya ditekan maka cairan yang menyerupai darah akan mengalir dari paru-paru ke arah jantung kemudian kembali lagi ke arah paru-paru. Disini siswa dituntut untuk lebih aktif terlibat secara langsung dalam kegiatan proses pembelajaran agar mendapatkan hasil belajar yang optimal. Dengan adanya media SEPEDA diharapkan pembelajaran IPA pada materi alat peredarah darah pada manusia dapat lebih baik. Berdasarkan latar belakang di atas, maka peneliti melakukan penelitian dengan judul "Pengembangan Media SEPEDA dalam Pembelajaran IPA di Sekolah Dasar".

\section{Metode}

Penelitian ini adalah penelitian Research and Development. Penelitian ini dilakukan di siswa kelas $\mathrm{V}$ di tiga sekolah yaitu SDN Blimbing 1, SDN Kedungmundu, dan SDN sendangmulyo 01. Dengan menggunakan teknik pengumpulan data yang digunakan adalah wawancara, observasi, dokumentasi, dan tes.

\section{Hasil dan Pembahasan}

Hasil dari pengembangan media SEPEDA efektif yaitu dengan perolehan nila preetest menunjukkan bahwa nilai yang didapatkan sebelum menggunakan media SEPEDA yaitu nilai paling tinggi sebanyak 30 dan nilai terendah 0 , dengan rata-rata nilai yang didapatkan siswa sebanyak 10,3. Hal ini berarti keseluruhan nilai siswa masih dibahawa KKM. Dengan berbantu media SEPEDA rata-ratanya naik sebesar 67,4 dengan nilai tertinggi sebesar 100 dan nilai terendah sebesar 20. Dengan ini berarti selisih peningkatan nilai sebanyak 57,1 .

Penelitian ini dilaksanakan di 3 sekolah yaitu SDN Kedungmundu Semarang, SDN Sendangmulyo 01, dan SDN Blimbing 1 pada kelas V. Setelah dilaksanakannya observasi awal ditemukan beberapa masalah seperti kurangnya motivasi siswa dalam belajar, emosi siswa kurang terkendali sehingga proses 
pembelajaran tidak kondusif. Selain permasalahan yang ada ditiga sekolah tersebut metode yang digunakan oleh guru saat mengajar adalah metode ceramah dan siswa belajar dengan buku paket saja, sehingga siswa merasa bosan dan jenuh dan akibatnya siswa lebih asyik dengan dunianya sendiri misalnya bermain sediri atau bahkan mengobrol dengan teman sebangkunya. Sehingga mengakibatkan hasil belajar siswa rendah dibawah KKM khususnya materi sistem peredaran darah kelas V mata pelajaran IPA.

Siswa membutuhkan media pembelajaran yang dapat memberikan gambaran nyata tentang bagaimana proses urutan sistem peredaran darah manusia. Oleh karena itu peneliti mengembangkan media SEPEDA "Sistem Peredaran Darah" dengan materi sistem peredaran darah manusia mata pelajaran IPA. Media pembelajaran ini bertujuan untuk meningkatkan pengetahuan siswa tentang materi sistem peredaran darah manusia mata pelajaran IPA sehingga media ini dikemas dengan menarik dan mudah dalam penggunaannya. Media SEPEDA "Sistem Peredaran Darah" pada mata pelajaran IPA disusun secara menarik dan sudah memenuhi kriteria kevalidan, kepraktisan, dan keefektifan berdasarkan dari ahli materi dan ahli media.

Ahli media yang menjadi validator dalam pembuatan media pembelajaran SEPEDA ini adalah Bapak Wawan Priyanto, S.Pd., M.Pd. dan Bapak Singgih Adhi Prasetyo, S.Sn., M.Pd. Sedangkan Ahli materi yang menjadi validator dalam pembuatan media pembelajaran SEPEDA ini adalah Ibu Filia Prima, S.Pd., M.Pd. Perolehan hasil uji validasi yang dilakukan oleh Bapak Wawan Priyanto, S.Pd., M.Pd. memperoleh hasil dengan rata-rata skor 85\% dengan kriteria "sangat baik". Validasi yang dilakukan oleh Bapak Singgih Adhi Prasetyo, S.Sn., M.Pd. memperoleh hasil dengan rata-rata skor 96\% dengan kriteria "sangat baik".

Sedangkan untuk hasil validasi ahli materi yang dilakukan oleh Ibu Filia Prima, S.Pd., M.Pd. memperoleh rata-rata skor 63\% dengan kriteria "baik". Setelah mendapatkan kriteria valid peneliti melanjutkan uji coba pada tiga sekolah dasar yaitu SDN Kedungmundu Semarang, SDN Sendangmulyo 01, dan SDN Blimbing 1 pada kelas V.

Peneliti melakukan penelitian di SDN Kedungmundu Semarang dengan jumlah siswa kelas V sebanyak 38 siswa. Peneliti memberikan angket respon siswa dan respon guru. Dimana peneliti memperoleh nilai dari respon guru dengan total skor sebanyak 45 dengan presentase $90 \%$ dan respon siswa mendapatkan total skor 326 dengan presentase 86\%. Demikian pula penelitian yang dilakukan peneliti di SDN Sendangmulyo 01 dengan jumlah siswa kelas V sebanyak 44 siswa, mendapatkan hasil dari respon guru sebanyak 46 dan rata-rata 96\%. Sedangkan untuk respon siswa mendapatkan skor 372 dan rata-rata 85\%. Kemudian peneliti melakukan penelitian di SDN Blimbing 1 dengan jumlah siswa kelas V sebanyak 27 siswa, di sekolah tersebut peneliti selain memberikan angket respon guru dan angket respon siswa. Peneliti juga menerapkan media SEPEDA kedalam proses pembelajaran sesuai RPP yang sudah dibuat. Hasil dari preetest memperlihatkan tidak ada siswa yang tuntas KKM. Nilai tertinggi yang didapatkan adalah 30 dan nilai terendah 0 . Dimana rata-rata yang didapat dalam mengerjakan preetest ini adalah 10,3 dengan kriteria "sangat kurang". Sedangkan untuk hasil nilai posttest yang didapatkan sebanyak 17 siswa mendapatkan nilai diatas KKM, sedangkan sebanyak 10 siswa masih dibawah KKM. Rata-rata yang didapatkan 67,4 dengan kriteria "baik" dengan nilai tertinggi yang didapatkan yaitu 100 dan nilai terendah 20. Dimana KKM mata pelajaran IPA adalah 65.

Pengembangan media SEPEDA “Sistem Peredaran Darah" materi sistem peredaran darah mata pelajaran IPA memiliki kelayakan dari ahli media sebesar 92\% dan ahli materi 63\%. Dengan kriteria layak digunakan sebagai media pembelajaran materi sistem peredaran darah mata pelajaran IPA.

Media SEPEDA ini dirancang khusus untuk materi sistem peredaran darah mata pelajaran IPA. Dengan adanya media SEPEDA dapat mendorong siswa untuk lebih aktif dalam pembelajaran dan siswa dapat bertanya jawab dengan guru menggunakan media SEPEDA, selain itu juga dapat meningkatkan hasil belajar siswa..

\section{Simpulan dan Saran}

Media SEPEDA (Sistem Peredarah Darah) materi sistem peredaran darah manusia mata pelajaran IPA dinyatakan layak setelah mendapatkan hasil validasi dari ahli media dan ahli materi dengan kategori "baik". Setelah dilakukannya revisi sesuai saran ahli media dan ahli materi dengan jumlah nilai yang diperoleh dari ahli media sebesar 92\% dengan kategori "sangat baik". Sedangkan perolehan nilai validasi dari ahli materi dengan jumlah 63\% dengan kategori "baik". Media SEPEDA mendapatkan respon yang baik dari siswa maupun guru. Dimana perolehan nilai dari respon siswa sebanyak 86\% dengan kategori "sangat baik" dan perolehan nilai dari respon guru sebanyak 92\% dengan kategori "sangat baik". Hal ini menunjukkan bahwa media SEPEDA dapat diterima baik oleh guru maupun siswa sebagai media pembelajaran mata pelajaran IPA materi sistem peredaran darah. Berdasarkan hasil dari preetest dan 
posttest yang dikerjakan oleh siswa kelas V SDN Blimbing I, hasil preetest memperoleh nilai sebesar 10,3 dengan kategori "sangat kurang" dengan nilai tertinggi 30 dan nilai terendah 0. Dimana KKM mata pelajaran IPA adalah 65. Sedangkan untuk hasil posttest mendapatkan hasil 67,4 dengan nilai tertinggi 100 dan nilai terendah 20 termasuk kedalam kategori "baik". Hal ini menunjukkan selisi peningkatan sebesar 57,1. Dengan ini membuktikan bahwa media SEPEDA sudah memenuhi kriteria efektif dalam meningkatkan hasil belajar siswa.

\section{Daftar Rujukan}

Aisyah Nurul, dkk. 2018. Efektivitas Penggunaan Alat Peraga Sistem Peredaran Darah Terhadap Hasil Belajar Peserta Didik Kelas VII SMP N 12 Kota Tegal. Jurnal Pendidikan MIPA Pancasakti Jurusan Pendidikan IPA (Vol : 2 No: 1 Tahun 2018).

Ali Usman, dkk. 2013. Pengelolaan Pembelajaran Ipa Ditinjau dari Hakikat Sains pada SMP di Kabupaten Lombok Timur. Journal Program Pascasarjana Universitas Pendidikan Ganesha Program Studi IPA (vol 3 Tahun 2013).

Azhar Arsyad. 2011.Media Pembelajaran. Jakarta: Rajawali Pers.

Daryanto. 2013. Media Pembelajaran. Yogyakarta: GAVA MEDIA.

Hamdani. 2011. Strategi Belajar Mengajar. Bandung: CV PUSTAKA SETIA.

Iskandar. 3013. Metodologi Penelitian Pendidikan dan Sosial. Jakarta: Referensi.

Kamil Mochamad Budiarto. 2017. Pengembangan Multimedia Pembelajaran Materi Sistem Peredaran Darah Pada Manusia Mata Pelajaran IPA Kelas V Sd Negeri Karangmloko 2. E-Jurnal Prodi Teknologi Pendidikan (Vol : 6 No 8 Tahun 2017)

Munadi Yudhi. 2013. Media Pembelajaran. Jakarta Selatan: REFERENSI.

Sanaky Hujair AH. 2013. Media Pembelajaran Interaktif-Inovatif. Yogyakarta: KAUKABA DIPANTARA.

Subyantoro. 2013. Teori Pembelajaran Bahasa. Semarang: Jl. Kelud raya No 2.

Sugiyono. 2016. Metode Penelitian Pendidikan. Bandung: ALFABETA.

Sukmadinata Nana Syaodih. 2015. Metode Penelitian Pendidikan. Bandung: PT REMAJA ROSDAKARYA

Suprijono Agus. 2017. Cooperative Learning Teori dan Aplikasi PAIKEM. Yogyakarta: PUSTAKA PELAJAR

Syafril dan Zen Zehendri. 2017. Dasar-Dasar Ilmu Pendidikan. Jl. Kebayunan No. 1: KENCANA

Thobroni M. 2017. Belajar dan Pembelajaran Teori dan Praktik. Maguwoharjo: AR-RUZZ MEDIA.

Tursinawati. 2013. Analisis Kemunculan Sikap Ilmiah Siswa Dalam Pelaksanaan Percobaan pada Pembelajaran Ipa di SDN Kota Banda Aceh. Jurnal Pionir (Vol : 1No 1 Tahun 2013).

Umar. 2013. Media Pendidikan Peran Dan Fungsinya Dalam Pembelajaran. Jurnal Tarbawiyah (Vol : 10 No 2 Tahun 2013).

Walid Ahmad. 2017. Stategi Pembelajaran IPA. Yogyakarta: Pustaka Pelajar.

Wiarto Giri. 2016. Media Pembelajaran Dalam Pendidikan Jasmani: Yogyakarta: Jl. Candi Gebang I No 23.

Wonorahardjo Surjani. 2010. Dasar-Dasar Sains Menciptakan Masyarakat Sadar Sains. Jakarta Barat: Jl Topaz Raya C2 No. 16.

Yuliyanto Eko. 2015. Pro-Lingkungan Dan Sains: Memanfaatkan Limbah Compact Fluorescent Lamp (Cfl). Jurnal Pendidikan Kimia Universitas Muhammadiyah Semarang.(Vol 3 : No 1 Tahun 2015). 